\title{
ANALISIS PERLAKUAN CARBURIZING TERHADAP SIFAT FISIK DAN MEKANIK PADA BAHAN SPROCKETIMITASI SEPEDA MOTOR
}

\author{
Andika Wisnujati \\ Program Vokasi, Program Studi D3 Teknik Mesin \\ Universitas Muhammadiyah Yogyakarta \\ Email: andika_wisnujati@yahoo.com
}

\begin{abstract}
ABSTRAK
Kemajuan industri dan teknologi semakin berkembang pesat, termasuk industri logam. Kemajuan industri logam memiliki peranan yang penting terutama dalam dunia otomotif yang banyak menggunakan material dari logam. Sprocket merupakan komponen utama dalam sepeda motor, sebagai transfer gaya putar dari mesin menuju ke roda, sehingga akan cepat aus karena akan terjadi gesekan antara rantai dengan gear pada waktu mentransfer gaya putar dari mesin. Pada penelitian ini sprocket mengalami proses carburizing (karbonisasi) yaitu proses memanaskan bahan sampai diatas suhu kritis $900^{\circ} \mathrm{C}-950^{\circ} \mathrm{C}$ dengan penahanan selama 1 (satu) jamkemudian didinginkan dengan media air. Carburizingbertujuan memberikan kandungan karbon lebih banyak pada bagian permukaan dibanding dengan bagian inti benda kerja, sehingga kekerasan permukaan diharapkan dapat meningkat.Hasil pengujian kekerasan sprocket imitasi didapat nilai kekerasan rata-rata 219.23 VHN dan sprocket genuine tanpa perlakuan panas yaitu sebesar $217.68 \mathrm{VHN}$. Hal ini dikarenakan pada sprocket imitasi terdapat kandungan kadar karbon dan silikon lebih besar setelah dilakukan carburizing.Hasil pengujian struktur mikro pada sprocket imitasi, struktur ferrit terbentuk dari proses pendinginan yang lambat dari austenit (baja hypoeutectoid)dan mempunyai konduktivitas panas yang tinggi sehingga struktur ini bersifat lunak serta ulet. Pada fasa struktur perlite terbentuk campuran antara ferit dan sementit. Pada 0,8\% karbon perlit yang tampak seperti pelat-pelat yang tersusun secara bergantian oleh perpaduan struktur antara struktur ferrit dan sementit, serta fasa struktur ini memiliki sifat ulet dan kekerasan yang cukup tinggi, kemudian sturktur mikro sementit senyawa besi karbon $(\mathrm{Fe} 3 \mathrm{C})$ bersifat keras pada pendinginan lambat bentuknya lamellar bersifat keras.
\end{abstract}

Kata kunci: sprocket, carburizing, sifat fisik dan mekanik.

\begin{abstract}
The progress of industry and technology is growing rapidly, including metal industry. This progress has an important role to support other industries, particularly in the automotive industries that uses a lot of metal material.Sprocket is a major component in motorcycles, as transfer turning force from the engine to the wheels, so that it will rapidly wear out because there will be friction between the chain with gear at the time of transfer the turning force from the engine. In this study sprocket undergoing of carburizing process (carbonization) that is the process of heating material to above the critical temperature $900^{\circ} \mathrm{C}$ $950^{\circ} \mathrm{C}$ with detention for 1 (one) hour and then cooled with water media. Carburizing process aims to give more on the surface than the core part of the workpiece, so that the surface hardness is expected to increase.The test results obtained average hardness valueof imitation sprocket is $219.23 \mathrm{VHN}$ and genuine sprocket without heat treatment that is equal to $217.68 \mathrm{VHN}$. These results are due to the content of carbon and silicon is greater after carburizing in the imitation sprocket.The test results on the microstructure of sprocket imitation, the ferrite structure formed by the slow cooling of austenite (hypoeutectoid steel) and has a high thermal conductivity, so that this structure is a soft and ductile.In phase perlite structure formed the mixture of ferrite and cementite. At $0.8 \%$ perlite carbon looked like plates are arranged alternately by a fusion between the structure of ferrite and cementite structure, and this structure phase has a resilient nature and the hardness is quite high, then the microstructures of iron compounds and carbon cementite $(\mathrm{Fe} 3 \mathrm{C})$ is hard on slow cooling lamellar shape.
\end{abstract}

Keywords: sprocket, carburizing, physical and mechanical properties.

\section{PENDAHULUAN}

Kemajuan industri dan teknologi semakin berkembang pesat, termasuk industri logam, terutama dalam dunia otomotif yang banyak menggunakan material dari logam. Teknologi Otomotif Sepeda motor semakin meningkat pesat seiring dengan peningkatan penjualan sepeda motor. Indonesia merupakan salah satu pengguna kendaraan sepeda motor yang terbesar di dunia setelah Cina dan India (Edo Rusyanto, 2012). Pembelian sepeda motormeningkat tiap tahunnya, sehingga jumlah sepeda motor tentunya 
akansemakin meningkat, Data AISI (Asosiasi Industri Sepeda motor Indonesia) menunjukkan selama tahun 2010 penjualan motor sebanyak 6.881.893 unit dan tahun 2011 sebanyak 7.580.104 unit. Dalam pengoprasiannya komponen sprocket selalu bergesekan dengan rantai dari sepeda motor dari gesekan tersebut yang menyebabkan keausan dan berkurangnya umur pakai. (Abrianto, 2007), karena sprocket sering kita ganti maka, jika harga gear Set AHM 125 ribu, Federal 110 ribu dan Indopart 90 ribu, maka jika kita menggantinya dengan yang asli maka harganya akan mahal dibandingkan dengan yang imitasi, selisihnya bekisar 30 ribu. Memahami persoalan diatas dan perbandingan harga yang begitu jauh bedanya, maka penelitian ini mencoba melakukan perbandingan kualitas sprocket genuine dan sprocket imitasi melalui proses carburizing.Batasan masalah dalam uji kekerasan sprocket genuine dan sprocket imitasi untuk melihat perbedaan bahan dengan batasan yaitu:Material yang digunakan menggunakan sprocket belakangmerek Honda karisma dan sprocket imitasi; pengujian mekanis untuk sprocket adalah uji kekerasan; sedang pengujian fisis dilakukan dengan struktur mikro; suhu yang digunakan $900^{\circ} \mathrm{C}$ dengan peningkatan suhu $10^{\circ} /$ menit dan penahanan yang di gunakan adalah 1 (satu) jam.Tujuan utama dari penelitian ini adalah: menegtahui bahwa proses carburizing dapat diaplikasikan pada spesimen sprocket; mengetahui perubahan sifat mekanis pada bahan sprocket; membandingkan kualitas sprocket genuine dan sprocket imitasi.

Berdasarkan pada hasil komposisi kimia pada benda uji gear sprocket standart dan gearsprocket racing, pada material gear sprocket tersebut diklarifikasikan termasuk baja karbon rendah jika dilihat pada nilai karbonnya $(0,025 \%$ - 0,35\% C). Pada gear sprocket standart mengandung unsur C: $0,159 \% \mathrm{Fe}$ : 98,20\% Si: $0,007 \% \mathrm{Ni}: 0,006 \% \mathrm{Cr}: 0,020 \% \mathrm{Mn}: 0,979 \% \mathrm{Zn}: 0,541 \%$ dan gear sprocket racing mengandung unsur $\mathrm{C}$ : 0,333\% Fe: 98,33\% Si: 0,209\% Cr: 0,029\% Ni: 0,313\% Mn: 0,700\%. Untuk material gearsprocketstandart nilai kekerasan rata-rata $448 \mathrm{HVN}$, sedangkan gearsprocket racing nilai kekerasan rata-rata 544,8 HVN(Soelaiman, 2006). Penelitian dari (Sugito. B, dkk, 2007) bertujuan untuk mengetahui perbandingan sifat fisis dan mekanis sprocket AHM dan ASPIRA yang di carburizing. Langkah-langkah Penelitian dengan cara memasukkan spesimen dalam kotak yang diisi dengan bubukan arang tempurung kelapa, kemudian dipanaskan hingga suhu mencapai $900^{\circ} \mathrm{C}$ ditahan selama 1 jam dan didinginkan diudara bebas. Pada pengujian kekerasan pada sprocket AHM sebesar 950.8 HVN, pada sprocket ASPIRA sebesar 904.4 HVN dan 927.0 HVN untuk ASPIRA yang di carburizing, dengan demikian terjadi penambahan unsur karbon sebesar $2.5 \%$. Sedangkan pada pengamatan struktur mikro untuk AHM dan ASPIRA baik yang di carburizing maupun tidak terlihat fase martensit yang mendominasi. Penelitian (Amin, Solechan 2008) untuk menganalisa peningkatan sifat mekanik material sprocketgear Suzuki imitasi, setelah dilakukan proses carburizing. Adapun variabel bebas yang digunakan sprocket gear Suzuki genuine part, dan sprocketgear Suzuki imitasi dan sudah mengalami perlakuan panas, media quenching oli mesin SAE 40, dengan variasi temperatur $\left(850-950^{\circ} \mathrm{C}\right)$ dengan penahanan waktu 7 jam. Hasil yang diperoleh dari penelitian sprocketgear Suzuki imitasi. Pengujian yang dilakukan adalah pengujian kekerasan dan pengamatan struktur mikro. Sifat mekanik material sprocketgear Suzuki imitasi, dengan proses carburizing peningkatan nilai kekerasan optimal pada suhu autenisasi dengan temperatur $950^{\circ} \mathrm{C}$, kekerasannya meningkat 49,21\% dibanding dengan sprocketgear Suzuki imitasi tanpa carburizing, dan lebih tinggi 7,64\% diatas nilai kekerasan sprocketgear Suzuki genuine part.

Sprocket sepeda motor seperti tertera pada gambar (1), juga mempunyai kekuatan yang berbedabeda misalnya sprocket geniune adalah salah satu produk yang telah teruji dan ber standart dari segi bahan, kualitas dan mutu. Sprocket imitasi yang jauh dari standart pembuatan nya masih diragukan dari segi bahan kualitas, dan mutu produk tersebut. Tapi dari perbandingan ke dua sprocket tersebut kita belum bisa mengambil kesimpulan, bahan mana yang lebih mempunyai kualitas dan mutu yang lebih baik. Sprocket sepeda motor merupakan salah satu komponen penggerak roda. Berikut ini adalah gambar roda gigi sprocket yang akan diuji dilaboratorium.

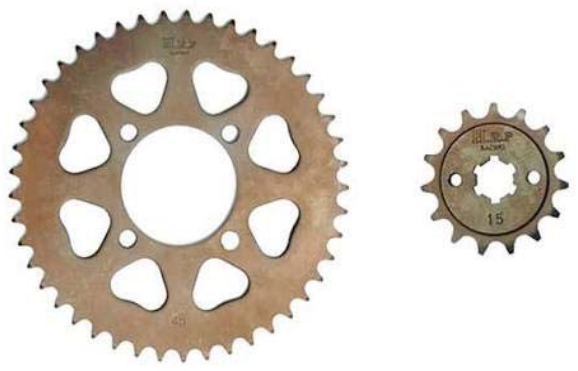

Gambar 1. Sprocket [2]

Baja karbon merupakan salah satu jenis baja paduan yang terdiri atas unsur besi (Fe) dan karbon (C). Dimana besi merupakan unsur dasar dan karbon sebagai unsur paduan utamanya. Dalam proses 
pembuatan baja akan ditemukan pula penambahan kandungan unsur kimia lain seperti sulfur (S), fosfor $(\mathrm{P})$, slikon $(\mathrm{Si})$, mangan $(\mathrm{Mn})$ dan unsur kimia lainnya sesuai dengan sifat baja yang diinginkan. Baja karbon memiliki kandungan unsur karbon dalam besi sebesar 0,2\% hingga 2,14\%, dimana kandungan karbon tersebut berfungsi sebagai unsur pengeras dalam struktur baja.

\section{METODOLOGI PENELITIAN}

Langkah-langkah penelitian yang dilakukan adalah sebagai berikut : (1) Pemotongan bahan sprocketgenuine dan sprocket imitasi seperti pada gambar 2 (a) dan (b) dengan menggunkan gergaji mesin yang diberi pendinginan media air, agar tidak mengalami perubahan sifata mekanis pada spesimen sprocket. (2) Bahan yang digunakan adalah sprocket genuine merek Honda Karisma dan sprocket imitasi; (3) Perlakuan permukaan bahan dilakukan pada sprocket imitasi dengan metode Gas Carburizing.
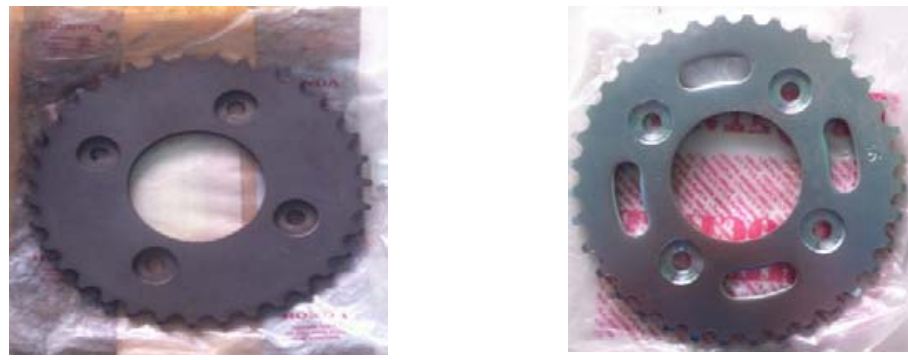

(a)(b)

Gambar 2. (a) Sprocket Genuine Honda; (b) Sprocket Imitasi

\subsection{Pengujian Kekerasan Vickers}

Pada pengujian ini identor menggunakan intan kasar yang dibentukmenjadi piramida. Bentuk lekukan intan tersebut adalah perbandingan diagonal panjang dan pendek dengan skala 7:1 yang ditunjukkan pada gambar 3 dibawah ini. Pengujian ini untuk menguji suatu material adalah dengan menggunakan beban statis. Bentuk identor yang khusus berupa knoop memberikan kemungkinan membuat kekuatan yang lebih rapat di bandingkan dengan lekukan Vickers. Hal ini sangat berguna khususnya bila mengukur kekerasan lapisan tipis atau mengukur kekerasan bahan getas dimana kecenderungan menjadi patah sebanding dengan volume bahan yang ditegangkan.

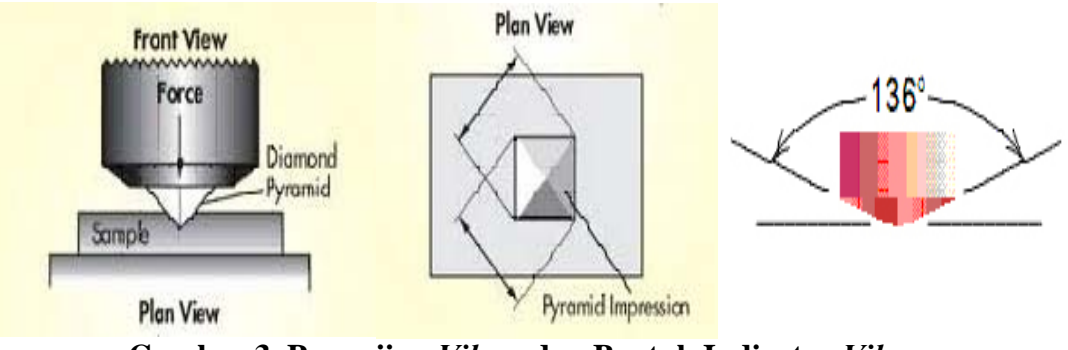

Gambar 3. Pengujian Vikers dan Bentuk Indicator Vikers

\subsection{Perlakuan Panas (Heat Treatment)}

Perlakuan panas merupakan suatu proses untuk merubah sifat-sifat dari logam sampai suhu tertentu kemudian didinginkan dengan media pendingin tertentu pula. Baja merupakan jenis logam yang banyak mendapatkan perlakuan panas untuk megubah sifat mekanik sesuai dengan keinginan namun terlebih dahulu diketahui instalasi dari baja tersebut seperti ditunjukkan pada diagram proses heat treatment pada gambar 4 dibawah ini. Salah satu proses heat treatment tersebut adalah quenching, yaitu suatu proses pengerasan baja dengan cara baja dipanaskan hingga mencapai batas austenite dan kemudian diikuti dengan proses pendinginan cepat melalui media pendingin air, oli, atau air garam, sehingga fasa autenit bertransformasi secara parsial membentuk struktur martensit. Tujuan utama dari proses quenching ini adalah untuk menghasilkan baja dengan sifat kekerasan tinggi. 


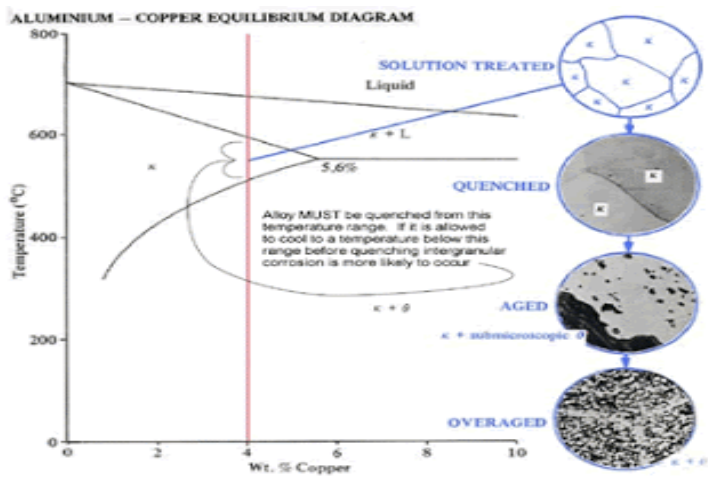

Gambar 4. Perlakuan Panas (heat treatment) [2]

Quenching Metode pencelupan secara cepat yang di sebut quenching, pada proses ini diperoleh struktur martensit akibat dari penurunan temperatur dan suhu austenit ke suhu kamar yang menyebabkan logam menjadi keras (Proses quenching ditunjukkan pada gambar 5). Pendinginan secara mendadak dari $700^{\circ} \mathrm{C}$ lebih adalah suatu pengerjaan yang sangat drastis, dan pendingan yang cepat ini akan mengakibatkan keretakan dan pergeseran benda kerja. Sejumlah media digunakan dalam quenching untuk mendapatkan variasi pendinginan. Larutan soda akustik 5\% memberikan pendinginan yang sangat dahsyat, lali dimasukkan air asin, kemudian air dingin. Air hangat, minyak mineral, minyak binatang, dan sayur-saturan menberikan pendingingan yang lambat,(Mulyadi,2007) Efek pendinginan yang lambat pada teras terutama pada benda-benda yang besar, adalah bagian dalam baja hampir tidak sekeras bagian luarnya. Oleh karena itu akan terjadi pengendapan karbon, dan bagian tengah baja akan mengandungpearlite. Hal ini tidak merugikan, karena teras yang sedikit lebih lunak akan mengubah keadaan menjadilebih rapuh dan kuat.

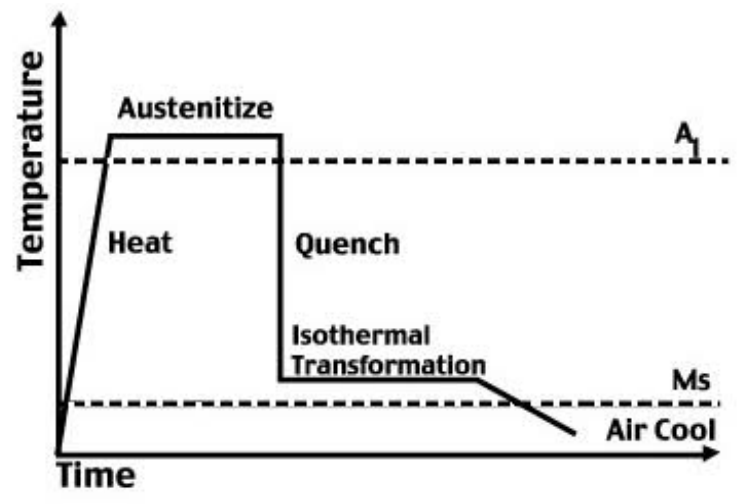

Gambar 5. Proses Quenching

\subsection{Carburizing}

Pada suatu komponen mesin dari baja adakalanya diperlukan keras dan tahan aus pada permukaannya saja, sedangkan pada inti atau bagian dalam tetap dalam keadaan lunak dan ulet. Hal ini akan memberikan kombinasi yang serasi antara bagian luar atau permukaan benda kerja yang keras dan tahan menerima beban, serta tahan aus dengan inti yang lunak dan ulet. Carburizing adalah proses menambahkan karbon ke permukaan benda, dilakukan dengan memanaskan benda kerja dalam lingkungan yang banyak mengandung karbon aktif, sehingga karbon berdifusi masuk ke permukaan baja. Pada temperatur Carburizing, media karbon terurai menjadi CO yang selanjutnya terurai menjadi karbon aktif yang dapat berdifusi masuk ke dalam baja dan menaikkan kadar karbon pada permukaan baja. Pada proses perlakuan panas, termasuk karburising selalu mengacu pada diagram fase yang berdasarkan pada karbon dari baja. Baja pada dasarnya adalah paduan besi dan karbon (Fe-C), besi dan karbon selain dapat membentuk larutan padat juga dapat membentuk senyawa karbid besi (Sementit, Fe3C). Dalam diagram fase, baja dibedakan menjadi tiga kelompok utama, yaitu :
a. baja eutectoid
b. baja hypoeutectoid
c. baja hypertectoid 
Carburizing yang digunakan pada penelitian ini adalah metode gas carburizingCarburizing dalam media gas lebih menguntungkan dibanding dengan carburizing jenis lain nya karena permukaan benda kerja tetap bersih, hasil lebih banyak dan kandungan karbon pada lapisan permukaan dalam dikontrol lebih teliti.

\subsection{Struktur Mikro (Metalografi)}

Metalografi adalah metode yang digunakan untuk memperoleh gambar yang menunjukkan struktur mikro pada hal ini struktur logam dan paduannya. Dengan pengujian mikrografi ini kita dapat mengetahui struktur dari suatu logam dengan memperjelas batas-batas butir logam. Dalam setiap butir, semua sel satuan teratur dalam satu arah dan satu pola tertentu. Batas butir mempunyai lima derajat kebebasan, Pada batas butir antara dua butir yang berdekatan terdapat daerah transisi yang tidak searah dalam kedua butiran tadi. Batas butir dapat kita anggap berdimensi dua, bentuknya mungkin melengkung dan sesungguhnya 28 memiliki ketebalan tertentu yaitu antara dua sampai tiga jarak atom. Ketidak seragaman orientasi antara butiran yang berdekatan menghasilkan tumpukan atom yang kurang efisien sepanjang batas.Analisis struktur mikro digunakan untuk menentukan apakah parameter struktur berada dalam spesifikasi tertentu dan didalam penelitian digunakan untuk menentukan perubahan-perubahan struktur mikro yang terjadi sebagai akibat komposisi atau perlakuan panas. Dengan analisa mikro struktur, kita dapat mengamati bentuk dan ukuran kristal logam, kerusakan logam akibat proses deformasi, proses perlakuan panas, dan perbedaan komposisi. Sifat-sifat logam terutama sifat mekanis dan sifat fisis sangat dipengaruhi oleh mikro struktur logam dan paduannya, disamping komposisi kimianya. Struktur mikro dari logam dapat diubah dengan jalan perlakuan panas ataupun dengan proses perubahan bentuk (deformasi) dari logam yang akan diuji. Pengamatan metalografi dengan mikroskop umumnya dibagi menjadi dua, yaitu:

a. Metalografi makro, yaitu pengamatan struktur dengan perbesaran $10-100 \mathrm{kali}$,

b. Metalografi mikro, yaitu pengamatan struktur dengan perbesaran diatas 100 kali.

Analisa mikro adalah suatu analisa mengenai struktur logam melalui pembesaran dengan menggunakan mikroskop khusus metalografi. Dengan analisa mikro struktur, kita dapat mengamati bentuk dan ukuran kristal logam, kerusakan logam akibat proses deformasi, proses perlakuan panas, dan perbedaan komposisi. Sifat-sifat logam terutama sifat mekanis dan sifat fisis sangat dipengaruhi oleh mikrostruktur logam dan paduannya, disamping komposisi kimianya. Struktur mikro dari logam dapat diubah dengan jalan perlakuan panas ataupun dengan proses perubahan bentuk (deformasi) dari logam yang akan diuji.

\section{HASIL DAN PEMBAHASAN}

\subsection{Pengujian Kekerasan Vickers}

Uji kekarasan Vicker menggunakan penumbuk piramida intan yang dasarnya berbentuk bujur sangkar. Angka kekerasan piramida intan yang disarnya berbentuk bujur sangkar. Angka kekerasan piramida intan $(D P H)$ satu angka kekerasan Vickers (VHN), di defenisikan sebagai beban di bagiluas permukaan lekukan. Luas ini di hitung dari pengukuran mikroskopik panjang diagonal jejak dapat ditentukan dari persamaan berikut:

$$
\begin{aligned}
\mathrm{VHN} & =\frac{1,854 \times \mathrm{P}}{n^{2}} \\
\mathrm{D} & =\frac{D 1+22}{\mathrm{x}}
\end{aligned}
$$

Dimana:

$\mathrm{F}=$ Beban yang ditetapkan

$\mathrm{D}=$ Panjang diagonal rata-rata

D1 = Panjang diagonal 1

D2 = Panjang diagonal 2

$\mathrm{D}=$ Panjang diagonal rata-rata

Pada pengujian kekerasan (Vickers) masing-masing spesimen diuji sebanyak 5 titik (seperti tertera dalam gambar 6 dibawah ini), setiap penekanan pada setiap masing-masing specimen tersebut, penekan 
menggunakan indentor piramid $136^{\circ}$ dengan beban penekanan $200 \mathrm{gr}$ dapat diperoleh data sebagai berikut:

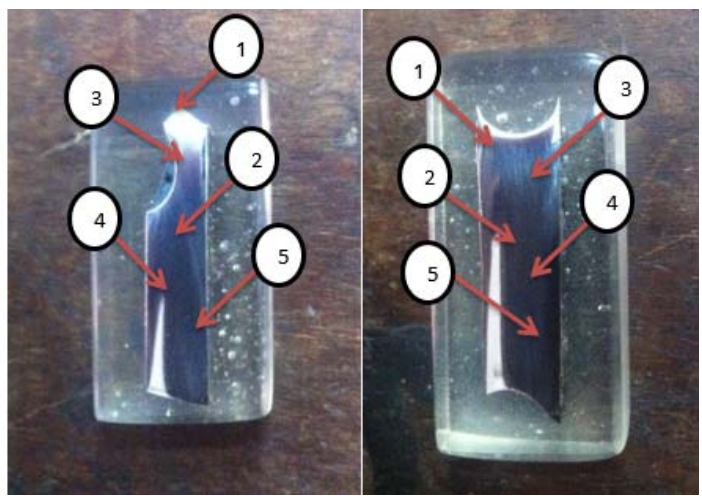

Gambar 6. Spesimen Uji Kekerasan

Tabel 1. Data hasil pengujian kekerasan vickers

\begin{tabular}{cccc}
\hline Titik & $\begin{array}{c}\text { Sprocket } \\
\text { Genuine }\end{array}$ & $\begin{array}{c}\text { Sprocket } \\
\text { Imitasi }\end{array}$ & Keterangan \\
\hline 1 & 330.40 & 228.88 & \\
2 & 330.40 & 212.72 & \\
3 & 110.22 & 189.37 & Beban 200 gr \\
4 & 139.80 & 179.10 & Indentor 136 \\
5 & 177.59 & 286.11 & \\
Rata-rata & $\mathbf{2 1 7 . 6 8}$ & $\mathbf{2 1 9 . 2 3}$ & \\
\hline
\end{tabular}

Pada pengujian kekerasan data hasil nilai kekerasan (pada tabel 1 dan gambar 7) dengan metodeVickers, untuk spesimensprocket genuine nilai kekerasan rata-rata $217.68 \mathrm{VHN}$, sedangkan sprocket imitasi nilai kekerasan rata-rata 219.23 VHN (dihitung menggunakan persamaan 1 dan 2). Jadi nilai kekerasan pada gearsprocket imitasi lebih tinggi setelah mengalami perlakuan panas, dibandingkan dengan sprocket genuine tanpa perlakuan panas, dikarenakan pada sprocket imitasi terdapat kandungan kadar karbon dan silikonnya lebih besar setelah dilakukan carburizing dibandingkan dengan gearsprocket genuine.Kadar karbon yang tinggi pada baja dapat menaikan kekuatan dan kekerasan material. Sedangkan unsur silikon mempunyai sifat ketahanan aus, dan ketahanan terhadap panas dan karat.

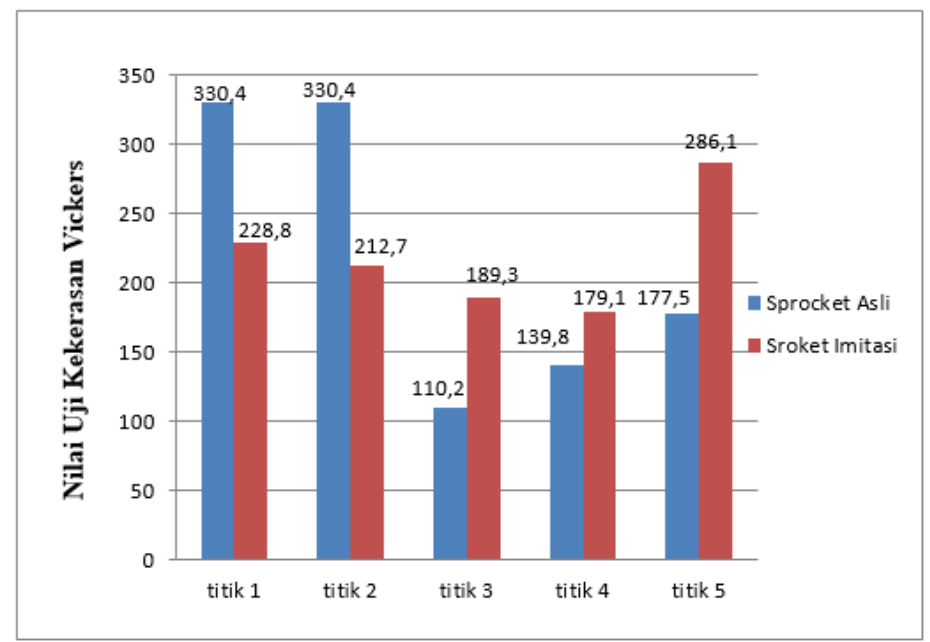

Gambar 7. Diagram Hasil Pengujian Kekerasan Vickers 


\subsection{Pengujian Struktur Mikro}

Pada pengujian struktur mikro (metalografi) dimaksudkan untuk mengetahui fasa-fasa yang terdapat pada gear sprocket genuine dan gear sprocket imitasi yang sudah di etsa dengan menggunakan mikroskop optik dengan pembesaran $200 \mathrm{x}$.

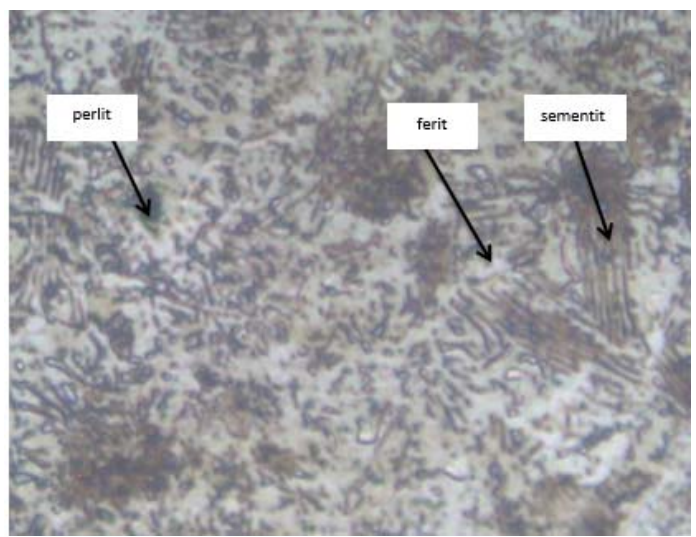

Gambar 8. Struktur Mikro Sprocket Genuine

Pada foto struktur mikrosprocketgenuineseperti terlihat pada gambar 8, terlihat struktur yang terbentuk adalah struktur ferrit (berwarna agak terang atau putih) dengan butiran butiran yang besar dan paling dominan.Struktur perlite (berwarna agak gelap) juga terlihat dalam struktur ini, dengan butiranbutiran yang agak besar dan sedikit.Kemudian struktur sementit (berwarna kecoklatan agak terang) juga terbentuk dalam fasa ini, dengan butiran-butiran yang besar dan banyak, tetapi tidak bagitu dominan.

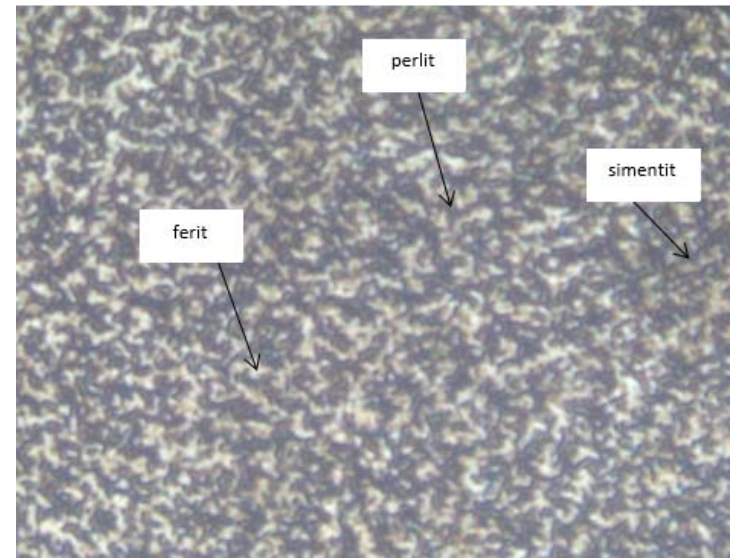

\section{Gambar 9. Struktur Mikro Sprocket Imitasi dengan Carburizing}

Pada gambar 9 tentang hasil uji sturktur mikro diatas, struktur ferrit terbentuk karena, terbentuk dari proses pendinginan yang lambat dari austenit (baja hypoeutectoid) dan mempunyai konduktivitas panas yang tinggi yang sangat banyak dan struktur ini bersifat lunak serta ulet. Berikutnya pada fasa struktur perlite terbentuk Campuran antara ferit dan sementti Pada 0,8\% karbon perlit yang tampak seperti pelat-pelat yang tersusun secara bergantian oleh perpaduan struktur antara struktur ferrit dan sementit, serta fasa struktur ini memiliki yang ulet dan kekerasan yang cukup kuat.Kemudian sturktur mikro sementit Senyawa besi dan karbon (Fe3C) Bersifat keras pada pendinginan lambat bentuknya lamellar pada struktur diatas bersifat keras.

\section{KESIMPULAN}

1) Pada proses carburizing dengan menggunakan suhu $900^{\circ} \mathrm{C}$ kenaikan suhu $10^{\circ} \mathrm{C} /$ menit dengan penahan selama 1 jam dan dilakuakan pendinginan cepat media air (Quenching liquid) pada spesimen sprocket dapat meningkatkan kualitas bahannya.

2) Uji kekerasan (Vickers) pada gearsprocket imitasi lebih tinggi dibandingkan dengan, sprocket asli dikarenakan pada sprocket imitasi telah diberikan perlakuan panas $900^{\circ}$ dengan penaikan suhu 
$10^{\circ} \mathrm{C} /$ menit penahanan $1 \mathrm{jam}$, kekerasan sprocket imitasi $219.23 \mathrm{VHN}$, sedangkan sprocket asli tanpa pengalami perlakuan panas $217.68 \mathrm{VHN}$.

3) Pada pengujian struktur mikro didapatkan data bahwa struktur ferrit terbentuk dari proses pendinginan yang lambat dari austenit (baja hypoeutectoid) dan mempunyai konduktivitas panas yang tinggi yang sangat banyak dan struktur ini bersifat lunak serta ulet.

\section{DAFTAR PUSTAKA}

[1] Amin dan Ahmadil, (2012), Pengaruh Besar Arus Temper Bead Welding Terhadap Ketangguhan Hasil Las Smaw Pada Baja St37, Vol. 4, ISSN, 2085-354

[2] Abrianto, (2007) Analisa keausan sprocket pada rantai. Univesitas Muhammadiyah Semarang.

[3] Amin dan Ahmadil, (2012), Pengaruh Besar Arus Temper Bead Welding Terhadap Ketangguhan Hasil Las Smaw Pada Baja St37, Vol. 4, ISSN, 2085-3548.

[4] Amanto, Hari. (1999), ilmu bahan Jakarta: Bumi Angkasa. Palallo, Frederick. 1995. Perlakuan Panas Logam. Bandung: PPPG Teknologi Bandung.

[5] Budinski (2001)," Engineering Materials Properties and Selection," PHI New Delhi, pp. 517536.

[6] Callister, W. (2001), Fundamental, of Materials Science and Engineering “Jhon Wiley And Son, Inc.

[7] Monden, Y., 1993. Toyota Production System: An Integrated Approach to Just-in-Time, $2^{\text {nd }}$ ed., Industrial Engineering and Management Press, Norcross, GA.

[8] Rusyanto, E., 2012. "Edo Rusyanto's Traffic" https://edorusyanto.wordpress.com/2012/12/26/amanahmubes-rsa-2012/

[9] Smith, F. William. (1995), Material Science and engineering. (second edition). New York: Mc GrawHill inc.

[10] Surdia,T. dan Shinroku, (1982), Pengetahuan Bahan Teknik, PT Pradnya Paramita, Jakarta.

[11] Handbook ASM Internasional The Materials, Vol 1 : 329, Jakarta, 1995. 